\title{
Manifestation of emergent properties in risk assessment of oil and gas companies
}

\author{
Inesa Khvostina $^{1,}{ }^{*}$, Nataliia Havadzyn ${ }^{1}$, and Nataliia Yurchenko $^{2}$ \\ ${ }^{1}$ Ivano-Frankivsk National Technical University of Oil and Gas, Department of Applied Economics, Ivano-Frankivsk, Ukraine \\ ${ }^{2}$ Ivano-Frankivsk National Medical University, Department of Social Medicine and Public Health, Ivano-Frankivsk, Ukraine
}

\begin{abstract}
The article presents a study on risks in oil and gas industry and reveals their causes investigating enterprises activity as a result of emergent properties of systems. The original algorithm of risk assessment process based on emergent properties study is offered. A taxonomy approach and factor analysis are used for purposes of risk evaluation. The risk assessment consists of risks taxonomy, database structure development, identification of risks through impact factors evaluation; economic system emergent properties risks prediction, an integral risk level indicator calculation using taxonomy approach, correlation analysis of integral indicators of risk assessment, preventive measures for minimizing of negative impacts and reducing risks.
\end{abstract}

Oil and gas industry enterprises have a multi-layer organizational and production structure and a complex technological and production process. Making changes to structural and functional relationships, sharing of responsibilities and resources inside the enterprise and structural changes in the state economics are accompanied by a significant number of risks.

The process of risk assessment requires large amounts of information involving complex methodological approaches, adaptation of economic and mathematical models to software.

The problem areas of this study are: identification of the properties of the risks in oil and gas enterprises, modeling of emergent properties of these risks; taking into account the potential of endangered properties in risk assessment.

The essence of risk as a parameter was discussed in works of Ukrainian and foreign scientists [1, 2, 3, 4]. Oil and gas enterprises risks exposure was revealed in publications $[5,6,7,8,9]$. The studies mentioned above present the process of risk assessment using alternative and improved methodological approaches.

The overview of scientific publications shows insignificant differences in the views on the economic nature of the "risk" parameter. In the works $[1,2,3,4,10$, 11] the emphasis is on the probable negative consequences if a risk situation occurs and preventive measures to reduce them.

Some other authors [12] consider the process of business administration, taking into account the influence of various internal and external factors, including risks. The methods of dynamic optimization aimed at risk reducing were offered.

The following studies $[5,6,7,8]$ present the classification of risks in oil and gas companies' activity and suggest methodological approaches to their assessment.

\section{Risks in oil and gas industry}

It was figured out that the main risks inherent for functioning of oil and gas companies are (Fig. 1):

- internal (financial, investment, property, human resource, management, innovation, information, production, operational, technical, technological, liquidity);

- external (political, legal, socio-demographic, ecological, market, exchange, repayment, geological, weather, globalization).

The cause of financial risk is the lack of access to capital, high inflation, fluctuations in exchange rates, an unstable financial business model and weak financial capabilities of oil and gas companies.

Low level of attraction of investment projects (involving international financial markets as well), causes investment risk. A low level of liquidity, solvency and business activity reflects property risk. Personnel risk arises as a result of the impossibility of attracting third parties in delimitation of activities (transportation of natural gas, underground storages, gas extraction as a separate activity).

Unfortunately, the oil and gas business management system in Ukraine is obsolete, inefficient and does not meet up to date international standards (management risks).

The problems in acquiring experience of managerial innovations and innovations in the oil and gas production is considered to be innovative risk.

Gaps in information systems and security, large amounts of information, the complexity of their

* Corresponding author: inesa.hvostina@gmail.com 
distribution and usage make up the essence of information risk.

\begin{tabular}{|c|}
\hline EXTERNAL RISKS \\
\hline Political \\
\hline Legal \\
\hline Socio-Demographic \\
\hline Ecological \\
\hline Market \\
\hline Exchange \\
\hline Repayment \\
\hline Geological \\
\hline Weather \\
\hline Globalization \\
\hline I \\
\hline INTERNAL RISKS \\
\hline Property \\
\hline Informational \\
\hline Investment \\
\hline Operational \\
\hline Production \\
\hline Human Resource \\
\hline Innovative \\
\hline Liquidity \\
\hline Managerial \\
\hline Technological \\
\hline Financial \\
\hline
\end{tabular}

Fig. 1. Types of risks influencing oil and gas enterprises (Generalization made by authors).

The complexity of the production processes of the oil and gas companies from the exploration of the deposit through exploration and exploitation drilling, the development of oil and gas fields, transportation of hydrocarbons till the processing and marketing define the production risk. Technical risk is considered to be the result of worn-out or obsolete equipment and tools used in the production process. Management and production technologies used do not match international standards, ignore scientific and technological progress and cause technological risk.

The unstable political situation, the annexation of the Crimea and military actions in the Eastern regions of Ukraine characterize the political risk. Participation in international litigation, absence of an approved mechanism of compensation if gas is sold at regulated prices, controversial provisions in the current legislation give rise to regulatory legal risk. Socio-demographic risk is the result of low purchasing power of the population, a decrease in the birth rate and an increase in mortality, mass migration of population of working age. The impact of environmental risk appears due to the usage of obsolete equipment and production technology, improper organization and technology faults.
Geological risks affect oil and gas extraction process, resulting in uncertainty about the productivity of deposits and associated with licensed areas where development and extraction are in the process. The situation in Ukraine has become more complicated due to the relatively low quality of geological information and obsolete equipment and technologies that can lead to increased drilling costs and reduced production rates [9].

Globalization risks can cause the disappearance of not only a particular enterprise, but also the whole industry or its separate components. Standardization of goods and the unification of consumer preferences can be both an opportunity for market expansion and a threat to an individual enterprise. It depends on its possibility to operate according to world standards or find a niche to avoid global competition. Oil and gas enterprises might face the risk of loss if global society switches to alternative energy sources.

\section{Some aspects of risks emergent properties manifestation}

Any of the identified risks can cause the crisis for business entities, including oil and gas companies. Prediction of the risks caused by the emergent properties should be a prerequisite for adverse events monitoring. It allows to select and systematize factors by the field of their occurrence.

It should be mentioned, that the emergent properties manifestation arises when the risks are combined, since none of them can be considered separately from each other. In the meantime, each risk can be characterized by a wide range of indicative factors and the links between them.

The concept of emergence according to authors [13, 14] reflects such a situation, when an unexpected overall positive effect occurs as a result of the strategic interaction of selfish individuals.

Emergence of the system is characterized by the fact, that, one hand, its properties arise unexpectedly and, on the other hand, they exceed the additive properties of its separate elements. State differently, the properties of separate elements being connected to the system become the cause and the result of the sudden appearance of distinctive properties of this system. These elements had never characterized by these properties until they joined the system.

The difference between emergent properties and synergy is that the synergy effect does not exist out of bounds of properties of the elements of the system, although the overall effect exceeds the effect of each individual element. While the sign of emergence is the emergence of new properties that are not distinctive for each individual element.

Emergence is a consequence of the manifestation of at least three factors:

1) a sharp nonlinear gain of previously unnoticed property;

2) unpredictable bifurcation of any subsystem;

3) recombination of links between elements [16]. 
On the flip side of the coin, re-emergent property is explained as the repeated returns of negative factors, previously either unoccupied or uncontrolled. These factors usually appear over unpredictable consequences, significant financial losses or new risks.

It is important that if the risk assessment involves emergent properties evaluation, it aids identifying both future hazards and new opportunities in the development of enterprises. It becomes easier to see the emergence of new interconnections both internally and externally, and form a new approach of risk management aimed at identifying risks, reducing them and supporting selforganized tendencies. Excessive formalization in risk assessment has a very negative effect on the results of the assessment and makes it impossible to obtain a real picture for prediction the risks of enterprises.

For example to manage legal and environmental risks it is necessary to adopt international environmental quality standards in Ukraine to reduce the risk of environmental pollution and degradation.

A characteristic feature of the innovation risk of oil and gas enterprises in Ukraine is slow implementation of scientific and technological innovations. Also there is managerial risk, which is the complexity and affects several layers of the organizational and production structure of oil and gas enterprises. In combination we will get an emergent property - managerial innovation (optimization of organizational structure), which will reduce the level of risk. If we consider the combination of managerial and technological risks, then manifestations of emergent properties will result in improved management technology or more efficient management of the technological process. The phenomenon of combining legal risk with innovation is manifested in changes to the law; with management - in the implementation of international rules of law concerning oil and gas enterprises management; with technological - in the simplification of implementation (environmental norms as an example) in the technology of oil and gas production. One group of emergent risk properties can reduce the level of other. They can be the result of a combination of any risks, not just those been examined in the study.

Nowadays risk management properties change. The negative point is if we focus on the of direct-feedback system only, we will have no chance to see evolution of emergent properties. As a result, we will lose the opportunity to identify new dangers and benefits for oil and gas companies. Therefore, the risk assessment taking into account emergent properties of the management system, and not only its components (units, management decisions, resources, factors, etc.) is the result of the development and evolution of the entire risk management system.

Underestimation of the emergent or re-emergent properties can lead to major miscalculations in planning the activities in oil and gas companies, building relationships with groups of stakeholders, corporate governance, building a portfolio of projects to achieve their goals.

\section{Modifying risk assessment process using taxonomic procedures, factor analysis and taking into account the emergent properties of a system}

Any of the identified risks might result in the signs of a crisis at the economic activity of business entity, including oil and gas ones. Prediction of the risks caused by the emergent properties is a prerequisite for monitoring of unfavorable events. Such prediction makes it possible to choose and to systematize factors by their origin. Manifestation of emergent properties occurs when the risks are combined. The main reason of it is that none of those risks can be considered separately from each other. On the flip side of the coin, each of the risks is characterized by a wide range of indicative factors followed the wide variety of the links between them.

Taking into account the emergent and re-emergent properties is expedient in the process of risk assessment, whereas it makes possible to foretell and predict risks which oil and gas companies might be facing.

Modern qualitative and quantitative risk assessment methods allow us to identify the causes of hazards before they have influenced the oil and gas company. As a result, it becomes possible to implement the system of preventive management. Existing methods and recommendations, alone or in combination, enhance the prognostic capabilities of risk assessment approaches. However, each of these methods still ignores both emergent and reemergent properties in risk assessment and specifics of oil and gas companies.

Within the context of that problem, the authors offer to emphasize taxonomic procedures and methods of factor analysis taking into account the emergent properties of risks.

Using such an approach enables oil and gas companies to carry out a comprehensive risk assessment which lays the groundwork for both their further assessment and forecast of their dynamics.

In accordance with the algorithm (Fig. 2), the first stage is defined as "Generating of risk taxonomy". This stage includes:

- identifying possible causes of risk;

- definition and formation of a variety of internal and external risks affecting the economic activity of oil and gas companies.

Afterwards, the specific areas of oil and gas companies' activity are considered. The most important of them are:

- the occurrence depth of productive formation of minerals exploration,

- drilling of oil and gas wells,

- exploration of oil and gas fields,

- extraction of hydrocarbon raw materials,

- ransportation,

- processing,

- torage.

These spheres act as subjects of risk. That is why it provides insight into the process of their type identifying.

Further risks for different fields of activity of oil and gas enterprises are singled out. Before it the statistical 
sources analysis should be done and main selection indicators have to be reasoned.

\begin{tabular}{|c|c|}
\hline \multicolumn{2}{|l|}{$\begin{array}{c}\text { Stage 1 } \\
\text { Generating of risk taxonomy }\end{array}$} \\
\hline $\begin{array}{c}\text { Risks affecting } \\
\text { different aspects of business }\end{array}$ & \\
\hline $\begin{array}{c}\text { Statistical data analysis } \\
\text { Impact factors determination }\end{array}$ & \\
\hline \multicolumn{2}{|l|}{$\begin{array}{c}\text { Stage } 2 \\
\text { Database structure developing }\end{array}$} \\
\hline Expert draft study & \\
\hline \multicolumn{2}{|l|}{ Indicators for each risk source } \\
\hline \multicolumn{2}{|c|}{$\begin{array}{c}\text { Stage } 3 \\
\begin{array}{c}\text { Identification of risks through influence factors } \\
\text { evaluation }\end{array}\end{array}$} \\
\hline Depending on research scope & \\
\hline Depending on research aim & \\
\hline \multicolumn{2}{|c|}{$\begin{array}{c}\text { Stage } 4 \\
\text { Economic system emergent properties risks } \\
\text { prediction for oil and gas companies } \\
\end{array}$} \\
\hline \multicolumn{2}{|c|}{$\begin{array}{c}\text { Stage 5 } \\
\text { The integral risk level indicator calculation } \\
\text { (a taxonomy approach) }\end{array}$} \\
\hline $\begin{array}{c}\text { A standardized observation matrix } \\
\text { developing }\end{array}$ & \\
\hline $\begin{array}{c}\text { Selection of a reference risk vector } \\
\text { depending on multi-vector parameters } \\
\text { study }\end{array}$ & \\
\hline \multicolumn{2}{|l|}{$\begin{array}{l}\text { Calculation of deviations of individual } \\
\text { elements from the reference vector }\end{array}$} \\
\hline \multicolumn{2}{|l|}{$\begin{array}{c}\text { The modified risk level indicator } \\
\text { calculation }\end{array}$} \\
\hline \multicolumn{2}{|c|}{$\begin{array}{c}\text { Stage } 6 \\
\begin{array}{c}\text { Correlation analysis of integral indicators of } \\
\text { risk assessment }\end{array}\end{array}$} \\
\hline Matrix completion & \\
\hline Indicators limits calculation & \\
\hline $\begin{array}{c}\text { Stage } 7 \\
\text { Preventive measures for minimizing } \\
\text { impacts and reducing risk }\end{array}$ & egative \\
\hline
\end{tabular}

Fig. 2. Modified risk assessment process with account to emergent properties. The taxonomy method and factorial analysis are applied (authors' original development).

At this stage a statistical database is being formed. This process involves labor-intensive work with large masses of information.

The second stage involves the database structure developing process, which can take place in two main aspects:

- based on an expert draft study. It is called "the pragmatic method" and characterized as rather subjective one;

- based on a system of indicators suitable for risk level assessing for any part the oil and gas enterprises activity or for the whole company.

An expert method refers to qualitative ones, nevertheless there are certain procedures that allow to quantify the level of risk.
As far as the indicators system is concerned, it is expedient to combine them in blocks, each of which corresponds to the sphere and specifics of the enterprise activity. That's mean we offer to group them by the subjects of risk.

The third stage, named "Identification of risks through influence factors evaluation" also has its specific features for oil and gas companies. It depends on:

- type of business;

- the scale of the study;

- the purpose of the study.

Identification of risks makes possible to classify them in detail according to the influence factors. For that purpose, we separate stimulants and disintegrators.

On the other hand, the classification will ensure duplication avoidance. That means that we won't have any double consideration of the properties in the evaluation system.

For the purpose of the factors selection, both those having a significant impact on the oil and gas companies and insignificant ones, it is necessary to construct a planning matrix and conduct a preliminary experiment. According to its results, the influence of factors on the production process is estimated. Properly planned experiment produces significantly more information, provides key factors identification and assessment of their impact on the output integral indicator.

For instance, taking into account the specifics of oil companies, it is important to consider such factors as the risk of production processes continuity violation, malfunction on the hardware, a significant amount of fields with hardly extractable and depleted reserves, change of wells exploitation technologies and conditions as a result of the onset of the final stage of mining and other factors causing emerging technological risks.

Emergence here (in the process of oil and gas enterprises risks assessing) is characterized by the emergence of new risks that were not foreseen in determining the causes of occurrence at the first stage.

The fourth stage is "Economic system emergent properties risks prediction for oil and gas companies". The description of the properties of identified risks is a prerequisite for emergent and re-emergent risk properties forecasting by the type of oil and gas companies' business activity.

The fifths stage, mentioned as "The integral risk level indicator calculation (a taxonomy approach)", includes: - developing a standardized observation matrix; normalization procedure is performed according to the formula:

$$
Z_{i f}=\frac{x_{i f}-\bar{x}_{f}}{S_{f}}
$$

where $Z_{i f}$ - standardized value;

$x_{i f}$ - value of initial factor $x_{f}$ for the $i$-th period;

$\overline{x_{f}}$ is average by factor $x_{f}$;

$S_{f}$ is standard deviation by factor $x_{f}$;

- selection of a reference risk vector depending on multivector parameters study; reference selection $a_{f}$ for the factor $Z_{f}$ is performed by the formula: 


$$
a_{f}=\left\{\begin{array}{l}
\max _{1 \leq i \leq m} Z_{i f}, \text { if } Z_{f} \text { is the stimulant; } \\
\min _{1 \leq i \leq m} Z_{i f}, \text { if } Z_{f} \text { is the disintegrator; }
\end{array}\right.
$$

- convolution of standardized indicators into the integral indicator $I^{(d)}$ using the distance method:

$$
I_{i}^{(d)}=1-\sqrt{\sum_{f=1}^{n} w_{f}\left(a_{f}-Z_{i f}\right)^{2}},
$$

where $I_{i}^{(d)}-$ values of integral indicator, $i=1,2, \ldots, m$;

$w_{f}$-weights of indicators $Z_{f}, f=1,2, \ldots, n$;

$$
\sum_{f=1}^{n} w_{f}=1
$$

The distance method is quite common in various problems solving. The following studies $[18,19,20]$ were conducted on the construction of the integral index within the group by the distance method. A closer look to the literature on the risk assessment process of oil and gas companies, however, reveals a number of gaps and shortcomings.

- the identification of risk level.

An expert scoring method is offered for the purpose of weight risk assessment. In this case the following rating scale is used for $P_{i}$ :

- from 0 to 0,5 - low risk level;

- equal to 0,5 - medium risk level;

- from 0,5 to 1,0 - high risk level.

Choice of weight coefficients $w_{f}$ becomes usually a separate non-trivial task whichcould be solved through the expert assestment. The solution we offer to satisfy the needs of oil and gas companies risk assestment is to use the hierarchy coefficients allowing an expert to determine weights of indicators $Z_{f}$.

Estimated values of hierarchy coefficients could be determined on the basis of critical distancesthe that is the largest distance $d^{*}$ between the nearest adjacent factors $\left(Z_{i}, Z_{j}\right)$. This will determine the importance of the role of each factor in the entire research:

$$
d^{*}=\max _{i} \min _{j} d\left(Z_{i}, Z_{j}\right)
$$

To calculate the coefficient of the hierarchy all distances, which do not exceed the critical limit for each matrix factor, should be investigated according to the formula:

$$
Q_{i}=\left\{(i, j) \mid d\left(Z_{i}, Z_{j}\right) \leq d^{*}, j=1,2, \ldots, n\right\}
$$

Next step is connected with summing up the received distances. For each of the elements it is chosen the factor with the biggest amount of distances:

$$
\begin{gathered}
k_{m}=\max _{1 \leq f \leq n} k_{f} \\
k_{f}=\sum_{(i, j) \in Q_{i}} d\left(Z_{i}, Z_{j}\right)
\end{gathered}
$$

Thus, to determine the role, significance and position of each factor in ongoing research, we calculate the weight coefficient as the coefficient of the hierarchy according to the following formula:

$$
w_{f}=\frac{k_{f}}{k_{m}}
$$

The complexity of business processes at oil and gas companies' management requires systematization of statistical data array, factors, indicators, the risks as they are and their properties.

Taxonomic methods involve powerful but simple mathematical apparatus, do not require comparability of factors and properties and, on the top of that, are helpful when we need to considerate different levels of impact factors detail in the risk assessment.

The standardized observation matrix is constructed on the basis of the formed matrix of observations with adjustment to the coefficients of the hierarchy.

The standard risk vector is chosen in the variation between the maximum stimulant value and the minimum value of the disintegrator.

After it we calculate the deviation level. We have to know how much the individual elements differ from the reference vector.

The identification of the risk level reflects the trend of changes in stimulants and disintegrators, and consequently shows the resulting changes.

The matrix completion has to be done to implement of the sixth stage, mentioned as "Correlation analysis of integral indicators of risk assessment". Also here we calculate main indicators limits.

The density analysis is carried out by determining the coefficient of pair correlation. Correlation analysis provides determination of the influence degree of stimulants and disintegrators on the final result. The degree of dependence between the integral indicators is characterized by ties between them.

The final stage in the emergent properties-based risk assessment is "Preventive measures for minimizing of negative impacts and reducing risks".

Its peculiarity is that emergent property is described both as the emergence of new properties of the risks of the oil and gas enterprises, and the disappearance of some separate risks properties after their integration into the system [17].

The approach proposed has the disadvantage - the reference values depend on the sample. It means that for different samples we may have different reference values, and, therefore, different risk level assessments.

A way out of this situation is to determine as reference values the limit values of influencing factors that identify the maximum permissible risk degree. These values can be determined either from experience or through expert assessment of factors.

Taking into account the specifics of the oil and gas enterprises of the complex, we believe that the risk assessment method focused on emergent properties of system and based on taxonomy approach and factor analysis is applicable in modern economic situation. The advisability of its application for assessing risks in oil and gas industry depends on:

1) the level of complexity, adequacy and reliability of information about activities of oil and gas enterprises;

2) different levels of detailing of factors that characterize economic activity; 
3) the procedure of risk assessment explained in the article involves the construction of economic and mathematical models that take into account the qualitative, quantitative and structural characteristics of identified risks.

Prospects for further research in this direction include, on one hand, the problem of input factors choice and on the other hand, an approbation of the offered risk level assessment methodology depending on the features of the oil and gas enterprises, in particular on their specialization. Therefore, there are objective prerequisites for further research in this direction.

\section{References}

1. Vitlinskyi, V.V., Velykoivanenko, P.I.: Ryzykolohiia $\mathrm{v}$ ekonomitsi ta pidpryiemnytstvi. KNEU, Kyyiv (2004)

2. Granaturov, V.M.: Ekonomicheskiy risk: suschnost, metodyi izmereniya, puti snizheniya. Delo i Servis, Moscow (2010)

3. Lukianova, V.V.: Diahnostyka ryzyku diialnosti pidpryiemstva. Khmelnytskyi (2007)

4. Donets, L.I., Prudnikova, L.I.: Ryzyky dyversyfikatsii hospodarskoi diialnosti pidpryiemstva. Problemy i perspektyvy rozvytku pidpryiemnytstva.

http://nbuv.gov.ua/UJRN/piprp 2011 15

Accessed 23 March 2019

5. Horal, L.T., Fadieieva, I.G.: Finansovi aspekty innovatsiinoho rozvytku naftohazovoho kompleksu Ukrainy. Ivano-Frankivsk (2016)

6. Nemchenko, M.Yu.: Metodicheskiy podhod k otsenke riskov neftegazodobyivayuschih predpriyatiy. Ekonomicheskie nauki. 10(59), 141144 (2009)

7. Shumilova, V.M., Karataev, A.S.: Informatsionnaya model otsenki finansovyih riskov. Sovremennyie problemyi nauki i obrazovaniya. 5. http://www.science-

education.ru/ru/article/view?id=7086 Accessed 26 March 2019

8. Ustenko, A.O., Rishhuk, L.I.: Diahnostyka ryzykiv hospodarskoi diialnosti na pidpryiemstvakh naftohazovoho kompleksu. Naukovi pratsi Natsionalnoho universytetu kharchovykh tekhnolohii.

http://nbuv.gov.ua/UJRN/Npnukht 20093041 (2009) Accessed 23 March 2019.

9. Annual report of NJC "Naftogaz". http://annualreport2016.naftogaz.com/ua/de-mizaraz/osnovni-riziki/ (2016). Accessed 22 March 2019

10. Shandova, N.V.: The preventive analysis of risk factors of the development of industrial enterprises. Marketing and Management of Innovations. 1, 317326 (2018). doi:10.21272/mmi.2018.1-24

11. Sudomyr, S.M.: Formation of an effective risk management system for socio-economic systems, Visnyk KhNAU named after V.V. Dokuchaev Series of Economic Sciences. 1, 149-153 doi:10.31359/2312-3427-2018-1-149

12. Babenko, V., Chebanova, N., Ryzhikova, N., Rudenko, S., Birchenko, N.: Research into the process of multi-level management of enterprise production activities with taking risks into consideration. Eastern-European Journal of Enterprise Technologies. 1(3(91)) (2018). doi:10.15587/1729-4061.2018.123461

13. Ivashuk, Yu.P.: Emerdzhentnyi instytutsiinyi poriadok v ekonomitsi ta yoho povedinkovi pidstavy. Ekonomichna teoriia. http://nbuv.gov.ua/UJRN/ecte_2016_3_6 (2016). Accessed 23 March 2019

14. Smit, V.: Constructivist and environmental rationality in economic theory. From: Experimental Economics (a set of studies, the totality of which the author was awarded the Nobel Prize), pp. 419-504. Moscow (2008).

15. Geseleva, N.V., Zaritskaya, N.M.: Emergent properties of the system. Business-inform. 7, 93-97 (2013)

16. Grebeshkova, O.M.: Emergence in the strategic process of the enterprise. Formation of a market economy. 22, 129-137 (2009)

17. Khvostina, I.: Taxonomic analysis as a methodological reception of risk evaluation of oil and gas sector companies. In: Promising problems of economics and management, pp. 413-416. BREEZE, Montreal (2015)

18. Hryhoruk, P.M., Khrushch, N.A.: Complex assessment of level and dynamics of innovative capacity of region. Marketing and Management of Innovations. 3, 109-129 (2016)

19. Kalashnykova, K.M.: Zastosuvannia taksonomichnoho analizu dlia vyznachenia intehralnoho pokaznyka optymalnosti struktury kapitalu. Upravlinnia rozvytkom. 2(123), 112-115 (2012)

20. Osadcha, Yu.V.: Analiz rivnia rozvytku rehionalnykh rynkiv pratsi. Stalyi rozvytok ekonomiky. 1(11), 142-145 (2012) 